\title{
"Isto aqui não é escola, é zoológico. Lá estão os animais": Morte em tenra idade de Jonathan Kozol e as injustiças e violências promovidas pelo sistema escolar americano na década de 1960
}

"This is not a school, it's a zoo. There are the animals":

Death at an early age by Jonathan Kozol and the injustices and violence promoted by the American school system in the 1960s

"Esto aquí no es escuela, es zoológico. Allá están los animales": Muerte a una edad temprana de Jonathan Kozol y las injusticias y violencias promovidas por el sistema escolar americano en la década de 1960

Juliana de Souza Silva

Universidade Cruzeiro do Sul (Brasil)

https://orcid.org/0000-0002-2790-8479

http://lattes.cnpq.br/4587435154983848

juped@usp.br

\section{Resumo}

O artigo trata das relações entre professores e alunos e das opressões, violências e desigualdades presentes no sistema escolar norte-americano. Para tanto, examina as memórias de Jonathan Kozol, que no livro Morte em tenra idade, escrito em 1960, narra sua breve experiência como docente de uma escola segregada de Boston, nos Estados Unidos. Na ocasião da publicação de sua autobiografia docente, o autor ofereceu ao público uma obra importante para o questionamento da escola pública de seu país. Além disso, seu relato desvela o cotidiano escolar evidenciando os conteúdos escolares, as formas de ensinar e as condutas abusivas de seus colegas de profissão em relação aos alunos, que não correspondendo às suas representações de excelência, acabavam sofrendo violências físicas e simbólicas, como as que apresentavam a percepção da escola como sendo um "zoológico" e a dos estudantes como sendo "animais". Seu livro lança luz àquilo que automatizamos e naturalizamos e mostra-nos a literatura como possibilidade de formação e de conhecimento da realidade social, histórica e psicológica.

Palavras-chave: Relação pedagógica. Memórias autobiográficas. Violências. 


\begin{abstract}
This manuscript deals with the relationships between teachers and students and the oppressions, violence and inequalities present in the North American school system. For this purpose, the analysis of Jonathan Kozol's memoirs, who in his book Death at an Early Age (1960) recounts his brief experience as a teacher in a segregated school in BostonUSA, is here presented. At the time when he published his teaching autobiography, Kozol offered an important work to question public education in his country. In addition, his story unfolds the school day by showing the pedagogical contents, teaching approaches and abusive behaviors of his professional colleagues to their students who, not corresponding to their representations of excellence, ended up suffering physical and symbolic violence, such as those perceiving the school as a "zoo" and the students as "animals". His book evidences what we automate and naturalize and give us literature as a tool for education in the knowledge of social, historical and psychological reality.
\end{abstract}

Keywords: Pedagogical relationship. Autobiographical memoirs. Violence.

\title{
Resumen
}

El artículo trata de las relaciones entre profesores y alumnos y de las opresiones, violencias y desigualdades presentes en el sistema escolar norteamericano. Para eso, examina las memorias de Jonathan Kozol, que en el libro Muerte a una edad temprana, escrito en 1960, narra su breve experiencia como docente de una escuela segregada de Boston, en los Estados Unidos. En el momento en que publicó su autobiografía docente, el autor ofreció al público una importante obra para cuestionar la enseñanza pública de su país. Además, que su relato revela el día a día escolar evidenciando los contenidos escolares, las formas de enseñanza y las conductas abusivas de sus colegas de profesión con los alumnos que, no correspondiendo a sus representaciones de excelencia, acababan sufriendo violencia física y simbólica, como aquellas que se presentaban percibiendo la escuela como un "zoológico" y los estudiantes como "animales". Su libro evidencia aquello que automatizamos y naturalizamos y nos muestra la literatura como posibilidad de formación y de conocimiento de la realidad social, histórica y psicológica.

Palabras-clave: Relación pedagógica. Memorias autobiográficas. Violencias. 
Há algum tempo, durante a leitura do livro Cartas a Cristina: reflexões sobre minha vida e minha práxis, de autoria de Paulo Freire (2015), deparei-me com a indicação de Morte em tenra idade, escrito por Jonathan Kozol (1983) ${ }^{1}$, um professor estadunidense que relata sua experiência lecionando como substituto entre os anos de 1964 e 1965 em uma escola localizada em um gueto da cidade de Boston. Ao ler as impressões de Freire em relação à obra lida "quase de um fôlego" (op.cit., p.7) resolvi buscar por ela. De posse do livro, comprado a preços módicos em um sebo, compreendi o entusiasmo que a leitura lhe causou, pois assim como ele: "tudo no livro, à medida que ia lendo, me tocava fortemente, me fazia centrado nele, sem intenção nenhuma de deixá-lo" (op. cit., p.198).

Kozol (1983) desvela o cotidiano da escola onde trabalhou e assim apresenta elementos que nos auxiliam a pensar sobre as questões pedagógicas, sobre as relações estabelecidas na escola e, sobretudo, sobre as desigualdades existentes no sistema escolar e a conduta dos professores em relação aos alunos, que em sua imensa maioria, não atendiam às representações de excelência discente idealizadas por eles e, por isso, acabavam vivendo a experiência escolar de forma tortuosa, uma vez que eram submetidos tanto a violências físicas - não só permitidas como regulamentadas pelo estatuto das instituições da época -, quanto pelas simbólicas e mais difíceis de serem percebidas, pois consubstanciadas nos discursos preconceituosos e nos estigmas usados pelos professores para referirem-se à população negra. Tais visões também eram reafirmadas pelos livros a que os estudantes tinham acesso. Muitos deles reafirmavam a posição de inferioridade dos negros referindo-se a eles como "ignorantes" aos quais o homem branco, cujas atitudes eram tidas como exemplares, deveria ensinar a viver corretamente ("O homem branco entrou na África a fim de ensinar o nativo a viver") (op. cit., p.84). Buscava-se "substituir uma cultura de classe mais baixa, mas muito rica, por uma mistura composta de ideias insípidas da classe média" (op. cit., p.88).

Absurdos como os mencionados anteriormente não figuravam apenas entre as práticas docentes e nos livros didáticos, mas eram também orientados pelo currículo da cidade de Boston que espelhava tais posicionamentos contribuindo para o apagamento da história e das referências da população negra por considerá-la como menos civilizada. Caberia aos professores guiar os alunos aos conhecimentos realmente preciosos, e para fazê-lo, não se economizavam repreensões despropositadas e agressões físicas, muito mais para a correção de comportamentos e condutas do que para o ensino das crianças. $\mathrm{O}$ menosprezo pelas atividades dos alunos e os julgamentos feitos sobre eles funcionavam como consagrações negativas do habitus dos estudantes (BOURDIEU, 1989).

Neste artigo, a autobiografia docente de Kozol (1983) é tomada como possibilidade de conhecimento da realidade por permitir a discussão e a reflexão sobre o cotidiano

\footnotetext{
${ }^{1}$ Jonathan Kozol nasceu em Boston, nos Estados Unidos da América, em 1936. É escritor, ativista progressista e educador conhecido por seus livros sobre a educação pública de seu país. Formou-se em Literatura Inglesa na Harvard University e, posteriormente, estudou ficção em Paris. Após seu retorno aos Estados Unidos, tornou-se professor nas escolas públicas de Boston. Foi demitido por ensinar um poema de Langston Hughes, conforme descrito no livro Morte em tenra idade (Death at an Early Age), em que relata seu primeiro ano como professor. Por esta obra, Kozol recebeu o Prêmio Nacional do Livro em Ciência, Filosofia e Religião. Após sua demissão, envolveu-se profundamente no movimento pelos direitos civis. Lecionou, também, nas escolas públicas de Newton, o distrito escolar que frequentou quando criança. Lá ensinou por vários anos antes de se envolver mais profundamente no trabalho de justiça social e dedicar mais tempo à escrita. Kozol fundou o The Education Action Fund, um fundo de caridade sem fins lucrativos que fornece assistência direta a muitas crianças e famílias citadas em seus livros. Entre suas obras mais importantes estão Rachel and Her Children, um estudo sobre mães sem-teto e seus filhos, que recebeu o prêmio Robert F. Kennedy Book. E Savage Inequalities, que foi finalista do National Book Critics Circle Award, em 1992. Por Amazing Grace: The Lives of Children and the Conscience of a Nation, Kozol recebeu, em 1996, o Anisfield-Wolf Book Award, uma honra concedida anteriormente às obras de Langston Hughes e Martin Luther King.
} 
escolar. Por meio das memórias do autor e de sua denúncia em relação às perversidades cometidas na instituição onde trabalhou, o texto que se segue busca contribuir para a análise daquilo que muitas vezes naturalizamos e automatizamos durante $o$ desenvolvimento do trabalho docente.

\section{“- É a ausência do rabo que o convence de que ainda não virou rato.”}

Durante toda a leitura do relato de Kozol (1983) eu ficava pensando quais as marcas deixadas por uma escolarização que parecia muito mais propícia a destruir os alunos e a ressaltar o quanto eram inapropriados para corresponder ao esperado pelos professores. $\mathrm{O}$ menino Stephen, de oito anos de idade, parecia ser o mais inadequado dentre todos os alunos. É o que as menções feitas a ele em diversos momentos da narrativa me faziam pensar. Advindo de situação social completamente precária e vivendo sob custódia do Estado, o garoto não conseguia fazer direito nenhum dos trabalhos da escola. Estava no quarto ano, embora seu desempenho mal atingisse o nível do segundo, e era muito ruim em matemática e leitura. Mas, mesmo indo muito mal nos trabalhos escolares, Stephen era um ótimo artista, e justamente por seus desenhos serem bons e autênticos, causavam sérios problemas a ele por não "serem nítidos, ordenados e organizados" (op. cit., 20) como os queria a professora de Artes que privilegiava os desenhos mimeografados que deveriam ser coloridos de acordo com o estipulado por ela. O menino reagia às repreensões e imposições desligando-se da realidade e deslocando-se para um mundo só dele. A professora ao perceber sua atitude, sem se importar se estava destruindo um ser humano, dizia: "Dá isso aqui! Que bagunça! Que sujeira! Olhem o que ele fez! Misturou tintas! Não sei para que gastar papel bom com um menino destes!” (op. cit., p.21). E, diante dessas e de outras violências, Stephen "sob tantos aspectos já quase morrendo, morria uma segunda, uma terceira, uma quarta vez e última vez diante daquela fúria" (op. cit., p.21). O curioso é que durante toda a leitura não consegui perceber, exceto por parte de quem escreveu o livro denunciando as torturas a que aquelas crianças eram submetidas, sequer algum esforço para ensiná-las e tentar dotá-las das disposições que os professores diagnosticavam lhes faltar. Elas eram, frequentemente, punidas por não terem o que, geralmente, é fruto do acesso que uma origem social privilegiada possibilita. O solicitado aos alunos pressupunha aprendizagens na maioria das vezes desenvolvidas no exterior da escola, longe da escola e antes da escola (CATANI; GALLEGO, 2009). Mas ora, não seria a função da escola tentar ajudá-las a adquirir essas disposições? De que serve uma instituição que consagra os que têm mais condições para lidar com ela e necessitaram de menos investimentos escolares para passarem tranquilamente pela escolarização?

No decorrer da narrativa, fica difícil saber se naquela escola segregada e esquecida pelo poder público qualquer aluno que fosse correspondia ao ideal dos professores, pois o fato de serem negros acrescido da condição de serem pobres parecia já colocá-los, a princípio, diametralmente distantes do considerado bom e virtuoso. Utilizando-se do discurso de que educavam aquelas crianças oferecendo-as saberes e conhecimentos essenciais à sua vida, cometiam-se inumeráveis crueldades. Várias eram as formas de escancarar essa inadequação e de puni-la. Os castigos físicos eram uma delas, pois permitidos pelo Manual dos Professores de Boston que assegurava aos docentes o direito de executá-los como pode ser observado no trecho abaixo:

O castigo corporal não será aplicado quando puder agravar defeito físico existente ou produzir ou ameaçar produzir ferimento grave e duradouro. Os casos de castigos corporais devem ser relatados por escrito pelo professor na data da ocorrência... Tais relatórios devem 
declarar o nome do aluno, nome da testemunha, o número de varadas e a razão delas..." (op. cit., p. 26).

Alguns professores mostravam-se sóbrios em relação às agressões físicas e não encaravam tratar abertamente sobre o tema, mas outros não conseguiam conter uma inequívoca espécie de satisfação pelos feitos, revelando-se perversos ao relatarem suas experiências e a darem conselhos aos seus colegas de profissão sobre como melhor agir. Por vezes, referiam-se às surras cinicamente ou humoristicamente demonstrando todo o seu prazer de administrá-las:

"- Quando a vara desce, é preciso golpear de repente para surtir o efeito desejado." (op. cit., p. 31)

“- Deixe a vara passar a noite n’água ou no vinagre e verá como provoca uma dor aguda." (op. cit., p. 31)

“- Não se preocupe com a lei, mas trate de não ser visto nem pelo diabo." (op. cit., p.31)

“- Não se afeiçoe a eles, sinta o que sentir. Aqueles a quem mais ajudar é que lhe darão uma punhalada nas costas." (op. cit., p. 31)

“- Os que menos suporto são os safadinhos dos pequenos. Os do Primeiro e Segundo Ano. Não se pode fazer nada contra eles, nem mesmo levantar a mão.” (op. cit., p. 31)

Violências simbólicas também eram cometidas durante todo o tempo, essas pareciam ser mais refinadas e imperceptíveis, pois muitas vezes as cruéis repreensões eram compreendidas como inserção dos estudantes na cultura considerada legítima. Ocorre que algumas delas faziam com que os alunos se percebessem como animais diante das posturas dos professores. Em umas das passagens marcantes do livro, Stephen, o garotinho sobre o qual me referi anteriormente, fazia caretas defronte ao espelho e por esse motivo foi arrastado agressivamente pela professora apenas por gostar de ver a própria imagem refletida. Vendo-o todo agachado em um canto e com o olhar triste e perdido, Kozol foi até ele e disse:

se você ficar aí todo encolhido sem olhar para mim, vou achar que você quer que eu pense que é um ratinho.

Ele olhou depressa para si mesmo, olhou para mim, dando uma risada grotesca e depois respondeu com um sorriso de causar dó:

- Mr. Kozol, eu sei que não sou rato; rato tem que ter rabinho!

Jamais esqueci este caso e mais tarde contei-o a um psiquiatra de crianças cuja resposta tornou o fato ainda mais explícito e claro.

- É a ausência do rabo que o convence de que ainda não virou rato.

Isso pode ter sido dito de uma forma absoluta, com um dogmatismo de psiquiatra, difícil de aceitar pelo pouco espaço que deixa à dúvida e à incerteza. Neste caso, porém, não creio que o psiquiatra tenha ido longe demais. São as próprias professoras das escolas de Boston que há muito tempo vêm se referindo aos alunos que têm sob sua guarda como a "animais" e ao edifício da escola que os abriga como "zoológico" (op. cit., p. 23-24). 
Tais violências ajudavam o garoto a instituir imagens sobre si mesmo. Seu corpo parecia assimilar e evidenciar sua posição de inferioridade. Stephen "olhava para o chão, nunca para o alto. Não deixava o olhar afastar-se de certo ponto escolhido. Tinha os cotovelos rígidos e pregados no corpo" (op. cit., p.30). É difícil saber se eram as violências físicas ou as simbólicas que causam maiores prejuízos aos indivíduos. Contudo, é pertinente discutir os efeitos de tais ações moldadas por padrões de condutas préestabelecidos e capazes de instituir certas representações. A esse respeito, os apontamentos de Norbert Elias (2010) são sugestivos, pois, de acordo com o autor, tornarse adulto em nossa sociedade exige um grau elevado de controle autorregulador das pulsões e dos afetos. No entanto, por natureza os seres humanos não possuem mais do que o potencial biológico para realizarem essas regulações; eles possuem um dispositivo biológico que torna possível o controle de tais pulsões. O modelo deste controle não está dado pela natureza, desenvolve-se durante o crescimento da criança, no interior e através das relações com os outros, tendo a escola um importante papel na modelagem dos comportamentos. A forma como os professores se referem aos alunos, como os corrigem ou repreendem suas condutas contribuem para esta modelagem. Para tanto, os docentes lançam mão de uma série de critérios não-ditos que levam em consideração não apenas, mas também, a aparência física que é sempre socialmente marcada por aspectos como, por exemplo, a cor da pele ou as formas de se comportar ou de se vestir. Há, então, certa subjetividade que acompanha a percepção e os julgamentos docentes em relação aos seus alunos organizando-se em torno de oposições entre as características consideradas desejáveis, adequadas e valorizadas e as que não o são. O resultado disso é que os estudantes passam, sem saber, a serem julgados de acordo com classificações sociais e não pedagógicas (CATANI; GALLEGO, 2009). De acordo com Morales (2003), alguns elementos como a procedência étnica, grupo de origem, aspecto físico, sexo entre outras coisas acabam por influenciar as expectativas dos professores definindo o tipo de comportamento que vão dispensar aos seus alunos: cordialidade, elogios, críticas, e no caso das experiências relatadas por Kozol, também as agressões físicas.

Os julgamentos docentes, muitas vezes, transmutam-se em eufemismos escolares fazendo com que apreciações na realidade fundamentadas por critérios sociais não sejam perceptíveis e compreendidas como tal. Faz-se crer que o julgamento se refira à "pessoa" ou a "inteligência" e jamais à pessoa social ou racial (BOURDIEU, 2014, p. 221). Produzidos pela prática de gerações sucessivas, e em determinadas condições de existência, os esquemas de percepção que os professores constroem sobre o mundo funcionam como operadores práticos através dos quais os indivíduos agem inconscientemente e tendem a reproduzir a realidade. Assim, o julgamento professoral apoia-se em critérios difusos e jamais completamente explicitados levando em consideração tanto os trabalhos e exercícios escolares, como a pessoa física de seu autor (BOURDIEU, 1989). Entre os alunos, há aqueles que estão mais aptos a atenderem às solicitações feitas e por isso vivenciam mais confortavelmente a experiência escolar, enquanto há os que se sentem incapazes de atendê-las e passam a perceberem-se como sendo inaptos para os estudos, como se os indivíduos nascessem com mais ou menos predisposição para ele. Segundo Pierre Bourdieu (2019, p. 249), as possibilidades que um indivíduo tem de ser "inteligente" ou de se considerar laureado de um "dom" estão intimamente ligadas às condições de acesso ao capital cultural que permitiu a ele vivenciar o espaço escolar de forma tranquila e confortável. As disposições, frequentemente adquiridas muito antes do ingresso na escola, possibilitam que as respostas esperadas pelos professores sejam dadas com certa desenvoltura e confiança fazendo crer que são disposições naturais aquelas que na realidade foram cultivas por anos não sistematicamente. A ciência, sobretudo a Psicologia, 
legitima esse processo ao passo que busca medir o grau de inteligência dos indivíduos desconsiderando a história social que os precede.

Infelizmente o livro em questão neste artigo trata de apenas um ano da vida de Kozol como professor junto àqueles estudantes. Contudo, isso não me impede de perguntar quais as consequências que as práticas descritas pelo autor causaram a longo prazo na vida dos alunos? Como esses garotos e garotas contariam atualmente suas histórias escolares? O que mais os marcou? Será que essa instituição deu conta de afastar definitivamente essas crianças da escola fazendo-as acreditar em sua inaptidão para os estudos? Quais as marcas e as consequências deixadas pelo juízo feito pelos professores a esses alunos? Não tenho como responder às questões em relação às vidas apresentadas pelo autor. Entretanto, alguns autores já trataram do tema. Recorro a alguns deles nesse momento para estabelecer a reflexão.

\section{"Eu quero ser uma mulher inteligente"}

Na década de 1990, Maria Helena Souza Patto publicou o clássico estudo $A$ produção do fracasso escolar: histórias de submissão e rebeldia. Nele, a autora acompanhou a rotina escolar de quatro estudantes considerados "alunos problema", Ângela e Nailton eram dois deles. Mais de duas décadas depois, Amaral (2010) sai a procura dos adultos que aquelas crianças de outrora se tornaram e os encontra residindo na mesma localização. A dissertação de mestrado produzida por ela e intitulada Histórias de (re) provação escolar: vinte e cinco anos depois traz os depoimentos desses dois que tiveram experiências tortuosas de escolarização. Ângela era vista como uma aluna "fraca"; Nailton como "indisciplinado", ambos ouviam cotidianamente sobre o quanto eram inadequados para a escola. Seus depoimentos são marcantes por nos permitirem observar histórias de violência tanto físicas quanto psicológicas que muito se assemelham às relatadas por Kozol quando se refere ao tratamento dado aos alunos da instituição onde trabalhou. Além disso, possibilitam compreender as influências que tais experiências tiveram na percepção dos dois sobre sua imagem e sobre a escola. Sobre as violências físicas, ao rememorarem os anos de escola, ambos se referiram a certa "cordinha" com a qual eram punidos ou tinham os movimentos tolhidos quando se mostravam indisciplinados ou não se desempenhavam como desejado:

Ângela diz: "Eu lembro da professora Grace que ela...Por exemplo, acho que eu ficava bagunçando, não sei. Saía muito da cadeira e ficava lá. Aí ela pegava e amarrava. Amarrava com a cordinha, sabe, 'você vai ter que fazer lição!"” (op. cit., p. 92).

Nailton diz: "Ela [a professora] tinha uma cordinha e uma varinha de bambu. Ela batia mesmo, mas não tinha jeito, não. Quando você....Não tem o que dizer, vara torta você não conserta ela, não tem jeito. Nasceu torto, morre torto, não adianta. Para esse tipo de coisa é... Era tempo perdido, coitadinha." (op. cit., p. 141).

Os trechos acima chocam por mostrarem que as violências físicas eram corriqueiras na instituição. Entretanto, as lembranças mais marcantes, e talvez mais doloridas, parecem ser as que evidenciavam as ideias pejorativas que seus professores faziam deles, visto que tiveram a força de estruturar a longo prazo a percepção que constituíram sobre sua intelectualidade. Ângela, aos 32 anos na ocasião do desenvolvimento da dissertação de Amaral (2010, p. 96), diz-se "uma mulher inteligente", mas, por vezes, durante seu discurso, refere-se a esse atributo como algo ainda a ser conquistado, lançando para o futuro a 
possibilidade de sê-lo. A alternância em suas respostas entre ser e querer ser faz com que a pesquisadora pergunte a ela sobre como se via naquele momento. A resposta leva a crer que o fato de não ter estudado e se tornado uma "simples dona de casa" fazia com que ela se sentisse "humilhada" e "maltratada" (TRENTO; AMARAL, 2010).

\section{"Ah, depois que tacha, já era"}

A frase acima foi dita por Nailton, também já adulto, para descrever o peso que a estigmatização e a marginalização vividas na escola lhe causaram. A afirmação feita sugere o peso que as percepções docentes sobre ele, consubstanciadas nos adjetivos usados para (des) qualificá-lo, tiveram em seu percurso escolar quando sua família foi convencida de que havia a necessidade de medicá-lo por ser portador de algum distúrbio. A esse respeito, ele diz:

"Depois que você dá o nome, já era. Depois que pegou, a pessoa põe aquilo na cabeça. Nós era "triste" mesmo, isso era verdade, nós ia pra escola mesmo pra bagunçar o coreto. Nós era "triste". [...] Assim, você dá um nome que aquela pessoa é daquele jeito, e aí de repente as pessoas olham pra você assim" (op. cit., p.119).

E complementa:

"Ah, depois que tacha, já era. Parece que todos os professor te pega daquele jeito. Já tinha algumas que falavam 'como ele fica comigo e é assim assado'. Às vezes faltava professora, colocavam professora e falava 'ele foi assim assado', mas não falava que era igual ao que os outros falavam, mas é... Depois que tacha, já era” (op. cit., p. 119).

"Para quem recebeu dos outros, interpreta que seja triste daquele jeito, mas não é bem assim. Que eu não gostava de escola, isso é verdade" (op. cit., p.119).

As expectativas boas e ruins que os professores têm em relação aos seus alunos auxiliam a determinar seu comportamento e desempenho escolar funcionando como uma "profecia" que se "autorrealiza" e ajudando a estruturar as relações que os estudantes têm com a escola e com o conhecimento (Rosenthal e Jacobson, 1989). Nailton parece ter consciência acerca das consequências que a visão apresentada sobre ele causou para sua autoimagem. Contudo, referese a "ir bem na escola" como sendo uma característica inata ao dizer que "[...] quando a pessoa tem que ser não tem jeito. Já nasce daquele jeito. Para estudar não tem jeito. Não era muito o meu forte a escola, não. Essa era a real" (AMARAL; TRENTO, 2015, p.422). E, assim, justifica seus fracassos na instituição recorrendo à ideia de que há os naturalmente mais aptos a ocuparem esse espaço, como se essa capacidade fosse fruto de um "dom" e não das diferenças de classe que foram transformadas em diferenças de inteligência (BOURDIEU, 1983). Sendo assim, a vivência de processos de violência certamente contribuiu para o desfecho de sua história de relações com a escola. Nessas condições, havia mais obstáculos do que incentivos à aprendizagem (AMARAL; TRENTO 2015). Assim como havia muito mais obstáculos para as crianças da escola de Boston vitimadas por diversos absurdos como mais este: 
“- Esse menino não regula."

Ouvindo isso, perguntei-lhe se já lhe ocorrera indicar-lhe um tratamento. Foi um erro. Vim a saber mais tarde que a Professora de Matemática era contra a psiquiatria. À minha pergunta sobre tratamento para Stephen, respondeu que não pensara no assunto, mas, já que eu tinha mencionado o fato admitia que não estava de acordo. Quis saber por que motivo e ela disse-me que "o garoto só mentiria aos psiquiatras, diria que o maltratam na escola e que éramos todos cheios de preconceitos". Daí há dias, ao vê-lo encaminhar-se para o porão a fim de levar mais umas varadas, ela tornou a comentar, sem sentir a própria incongruência, que "o garoto não regulava" (KOZOL, 1983, p.29).

O trecho acima revela uma espécie de orquestração de violências. Stephen era agredido por seu comportamento considerado inadequado, ao mesmo tempo em que assimilava com base nos discursos docentes proferidos sobre ele ser um "[...] menino [que] não regula".

\section{"Aqueles livros não se referiam a elas. O que se referia a elas era óbvio..."}

Como dito anteriormente, a crueldade em relação aos alunos de Boston não se restringia às agressões físicas e às repreensões orais sobre seus comportamentos e aparência. A forma como os conteúdos escolares eram transmitidos era uma iniciativa de apagamento das referências de seus antepassados. No lugar, eram oferecidos referenciais brancos. Quando os livros didáticos reportavam alguma coisa sobre a população negra, faziam-no de maneira completamente estereotipada ou submissa. Segundo Kozol (1983), havia muita coisa no currículo oficial da cidade de Boston para dar apoio a esses materiais, bem como às condutas dos professores em relação aos alunos. Em certa ocasião, já cansado de presenciar tantos absurdos, ele tenta mostrar sua indignação aos colegas. $\mathrm{O}$ trecho abaixo se refere ao episódio que provocou sua reação:

Semelhante a isto, embora não impresso em livro, era um teste mimeografado sobre História Americana que o professor do Quarto Ano da minha escola utilizava há vários anos. O teste trazia uma lista de atributos e qualidades supostamente associadas a George Washington: "corajoso, rico, inteligente, sábio, bonito, bondoso, bom esportista, paciente, crente em Deus, espirituoso, bem vestido, bom cavaleiro". Destes atributos pedia-se à classe sublinhar os que haviam feito de George Washington "um grande líder". Só recebiam pontos as respostas que indicassem virtudes nobres. "Rico, bonito, bem vestido", eram erradas. Não se tratava, na realidade de uma aula sobre George Washington, mas de uma alimentação forçada de um tipo especial de moral:

ESTAS SÃO BOAS QUALIDADES

GEORGE WASHINGTON CONSEGUIU ALGO NA VIDA EIS AS QUALIDADES QUE O ENGRANDECERAM (op. cit., p. 84, caixa alta do autor).

A indignação do autor diante do ocorrido se dá, pois as respostas corretas ao teste não haviam sido retiradas de qualquer estudo sobre George Washington, mas "de um baú de boas qualidades ("moral e civismo", p. 84)". Além disso, ao omitirem todas as vantagens que haviam colocado o ex-presidente na posição que ocupou, eram ofertadas às 
crianças a falsa ideia de que bastava cultivar as mesmas virtudes para se tornarem presidente dos Estados Unidos, quando a única forma de chegarem a ocupar tal posição decorreria do conhecimento dos obstáculos ocasionados pela posição de desvantagem social, racial e educacional delas se comparadas a dele. Ao apresentar tal argumento à professora de leitura, Kozol (1983) escutou da docente que "elas [as crianças] não estavam na idade própria para receber tais revelações" (op, cit., p.86). Essa compreensão sustentava sua iniciativa de distorcer os conteúdos ou mesmo de omiti-los dos alunos.

O currículo da cidade de Boston dava aval ao desenvolvimento de práticas absurdas como a explicitada acima. Ao tratar das diferentes formas de planificação da prática docente, Philippe Perrenoud (1995) apresenta o entendimento de que há um currículo formal em que estão previstos os conteúdos gerais a serem desenvolvidos com os estudantes; há o currículo real, que nunca é a estrita realização daquilo planificado pela instituição e pelos professores por escapar parcialmente do seu controle; e há um currículo escondido, que escapa à formulação precisa ocupando o lugar do não-dito. Algumas aprendizagens estão em conformidade com o prescrito no currículo formal (que no caso da escola de Boston não ajudava muito), mas outras, mesmo passando praticamente despercebidas, estruturam certas formas de pensar. Nas sociedades escolarizadas os sistemas de pensamento só podem ser compreendidos levando-se em conta o sistema escolar que é capaz de construir certos hábitos de pensamento em uma geração e algumas espécies de senso comum sobre certas temáticas. As representações pejorativas sobre a população negra que se faziam presentes nas atitudes dos professores, assim como nas formas de retratá-los nos livros utilizados pelas crianças, pareciam ser o senso comum. Aliás, o que gerava desconforto entre os docentes e os dirigentes da instituição eram as posturas de Kozol e não as outras. Os livros seguiam as mesmas perspectivas opressivas observadas cotidianamente pelo autor, de modo que, mesmo quando os materiais oferecidos pelo poder público às escolas buscavam ressaltar outros aspectos, acabavam reafirmando a posição de inferioridade na qual tal população havia sido colocada. Fragmentos exemplares dessa afirmação podem ser observados no excerto abaixo, advindo do livro Nosso Mundo Hoje. Segundo Kozol (1983), praticamente todos os livros a que as crianças tinham acesso eram semelhantes a ele:

Do mesmo modo que no caso dos livros de estudos sociais, quando o editor fazia um esforço no sentido de encontrar algo que tivesse a ver com negros, a coisa tendia a tornar-se desconcertante e constrangedora. Um exemplo é a estória chamada "Nunca se sabe". Ela pareceu-me memorável, pois, consultando a memória não encontro outra, em qualquer livro, em qualquer estante da escola, que descreva uma criança negra americana. O problema é que a estória não consegue apresentar a criança a não ser sob uma luz escravista, supersticiosa, situada entre o patético e o cômico. Os negros não são descritos com malícia, mas condescendentemente, como criadinhos engraçados, melancólicos e amáveis de um senhor branco imponente, incrivelmente distante, mas também inesperadamente generoso (op. cit., p.89).

O povo das ilhas britânicas é, como o nosso, um povo mesclado. Seus ancestrais pertencem às raças robustas do norte da Europa; eram os celtas, anglos, saxões, dinamarqueses e normandos, cuja energia e habilidade aparecem ainda em seus descendentes. Com uma herança tão esplêndida, que poderia haver de mais natural para os britânicos do 
que explorar e colonizar várias partes do globo e, com o tempo, construir o maior império colonial do mundo? (op. cit., p.83).

A África precisa de mais capitalistas...São necessários gerentes brancos...para mostrar aos negros como trabalhar e administrar plantações... (op.cit., p.84).

O branco pode permanecer por certos períodos curtos e dirigir o trabalho, mas não deve...realizar ele mesmo os trabalhos. Deve contar com o trabalho feito pelo nativo (op. cit., p. 84).

Este outro trecho refere-se a um fragmento do livro de contos lido para as crianças:

Havia ainda um problema com esses livros de leitura, o velho problema dos contos legados ao preconceito gasto pelo tempo.

"Era uma vez uma mulher que tinha duas filhas, uma era linda, mas a outra feia".

Quem ler isto, não precisa olhar para a ilustração no topo da página, para adivinhar qual será a filha de cabelos louros e qual a de cabelos escuros. A de pele escura, a filha má, terá também espinhas ou talvez, manchas de carvão na pele, debaixo do nariz, ao longo do rosto e no maxilar. Segundo a história, cada uma das meninas vai visitar uma senhora misteriosa que mora debaixo da terra. Cada uma comporta-se de acordo com as expectativas. A filha boa comporta-se bem, trabalha assiduamente $\mathrm{e}$ recebe como recompensa uma banheira de moedas de ouro. A outra comporta-se mal, recusa-se a trabalhar, é egoísta, quer receber sem dar e recebe como castigo uma banheira de alcatrão. "E o alcatrão só saiu da pele dela quando ela deixou de ser preguiçosa" diz o autor, "levou muito tempo para ela aprender a lição” (op. cit., p.88-89).

A iniciativa de tentar oferecer aos alunos referências diferentes custou ao professor/autor diversas indisposições com o Comitê Escolar da cidade e com os professores da instituição onde trabalhava como substituto. Sua indignação se nutria da esperança de tentar modificar o cotidiano escolar dos alunos pelo menos durante as aulas pelas quais era responsável, quando a educação daquelas crianças era responsabilidade dele. Certa vez, ele levou para a sala de aula uma biografia de Martin Luther King que foi lida por algumas crianças e por suas mães, que entusiasmadas com a leitura, perguntaram sobre a possibilidade de terem cópias para oferecerem aos familiares ou amigos de presente de Natal. Ao constatar a motivação e a curiosidade das crianças pela leitura e sugerir que mais alunos pudessem acessá-la, Kozol (1983) foi advertido pela professora de leitura:

primeiro, eles [os livros] eram difíceis demais para a maioria dos alunos (o que não era verdade) e, por fim, que eram sobre gente negra.

- Eu poderia até utilizá-los - disse ela afinal, com a seguinte ressalva: Se houvesse na classe apenas crianças negras. Não seria justo para as crianças brancas forçá-las a ler também tais livros. Aqui não há só negros. Se fosse assim, seria diferente. Se esta escola fosse segregada, 
eu poderia utilizar esses livros. Mas não é. Temos crianças brancas aqui. Do jeito que estão as coisas, não seria justo nem direito (op. cit., p. 91).

A persistência do professor em apresentar outras referências aos seus alunos e o prazer que eles demonstravam ao conhecê-las acabou resultando em sua demissão ao final daquele ano letivo. Mas antes suas denúncias movimentaram a instituição e o Comitê Escolar da cidade, despertando a indignação das famílias dos estudantes. Os alunos e seus pais ficaram muito tristes e indignados com a dispensa do professor Kozol, diferentemente de seus colegas de profissão que não escondiam a satisfação pelo ocorrido. Aparentemente, as compreensões da professora de leitura eram partilhadas por praticamente todos que ali trabalhavam. Após a demissão, Jonathan Kozol reiniciou sua carreira profissional em outro lugar. Segundo Freire (2015), ele se tornou um importante educador dos Estados Unidos, como sua biografia também sugere. Não temos como saber quais foram os destinos de seus alunos entre os anos de 1964 e 1965 na cidade de Boston.

\section{Considerações finais}

Morte em tenra idade foi um livro inesquecível para mim e neste artigo eu não poderia escrever sobre qualquer outra obra que não fosse essa. Sempre que posso me refiro a ela nas aulas das disciplinas que leciono na graduação, sobretudo, nas que trato de avaliação e de toda a subjetividade envolvida nos julgamentos que os professores fazem de seus alunos. Com as memórias daquele ano letivo, Kozol denunciou as práticas arbitrárias e abusivas de seus colegas de profissão. Denúncias essas que tiveram papel importante no questionamento da escola pública norte-americana na época de sua publicação. Contudo, mais de cinquenta anos depois, o livro ainda traz muitos elementos a serem explorados, especialmente aqueles que se referem à descrição das práticas desenvolvidas pelos professores ao transmitirem os conhecimentos aos alunos e ao lhes ensinar formas de se relacionar com o conhecimento e com a cultura. As possibilidades de reflexão trazidas por sua obra são ricas e diversas. Claro está que muito ainda temos a discutir sobre as minúcias envolvendo o trabalho docente nas escolas e que leituras como essa nos dão importantes contribuições neste sentido.

Nas páginas do livro somos confrontados com diversas violências e injustiças cometidas por um sistema escolar excludente que cotidianamente mostrava aos alunos sua inadequação diante das expectativas dos professores. Tais expectativas pareciam ser instransponíveis independentemente dos esforços feitos, pois na raiz de tudo estavam questões raciais e sociais. Tanto as agressões físicas administradas, quanto os discursos depreciativos proferidos pelos professores cumpriam a função de punir as crianças por isso. As práticas desenvolvidas pelos professores convertiam em verdade escolar o que era sustentado, na realidade, por um julgamento social e, assim, concretizava-se o "assassinato espiritual e psicológico" das crianças como afirma Robert Coles no prefácio do livro (p.11).

A fertilidade de questões e de reflexões suscitadas a partir da leitura desta autobiografia docente evidencia as potencialidades que as obras literárias têm quando utilizadas como recurso para o desenvolvimento de possibilidades formativas. Na medida em que permitem o conhecimento da realidade social, histórica e psicológica, elas nos oferecem elementos profícuos para que se pense sobre a formação, a prática e as relações pedagógicas.

\section{Referências}

AMARAL, Daniele K. Histórias de (re) provação escolar: vinte e cinco anos depois. Dissertação de Mestrado, FEUSP, 2010. 
BOURDIEU, Pierre. La noblesse d'État: grandes écoles et sprit de corps. Paris: Editions de Minuit, 1989.

BOURDIEU, Pierre. O racismo da inteligência. In: Questões de Sociologia. Rio de Janeiro: Vozes, 2019, p. 248-251.

BOURDIEU, Pierre.; SAINT-MARTIN, Monique.. As categorias do juízo professoral. In: BOURDIEU, P. Escritos de Educação. 15 edição: Petrópolis, 2014.

CATANI, Denice Barbara.; GALLEGO, Rita de Cássia. Avaliação. São Paulo: Unesp, 2009.

ELIAS, Norbert. La civilisation des parents. In: psychologie, psychanalyse. Paris: Éditions la Découvert, 2010.

KOZOL, Jonathan. Morte em tenra idade. São Paulo: Loyola, 1983.

MORALES, Pedro. A relação professor-aluno: o que é, como se faz. $4^{\mathrm{a}}$ Ed., São Paulo: Loyola, 2003.

PATTO, Maria Helena Souza. A produção do fracasso escolar: histórias de submissão e rebeldia. $4^{\mathrm{a}}$ Ed. São Paulo: Intermeios, 2015.

PERRENOUD, Philippe. O currículo real e o trabalho escolar. In: O Ofício de aluno e o sentido do trabalho escolar. Porto: Porto Editora, 1995, p. 39-71.

ROSENTHAL, Robert.; JACOBSON, Lenore. Profecias auto-realizadoras na sala de aula: as expectativas dos professores como determinantes não intencionais da capacidade intelectual dos alunos. In: PATTO, M. H. S. (Org.). Introdução à psicologia escolar. São Paulo: T. A. Queiroz, 1981.

TRENTO, Denise Rebello de S.; AMARAL, Daniele K. Quatro histórias de (re) provação escolar - Notas sobre os rumos das vidas de Ângela, Nailton, Augusto e Humberto. In: PATTO, M. H. S. A produção do fracasso escolar: histórias de submissão e rebeldia. $4^{\mathrm{a}}$ Ed. São Paulo: Intermeios, 2015. 